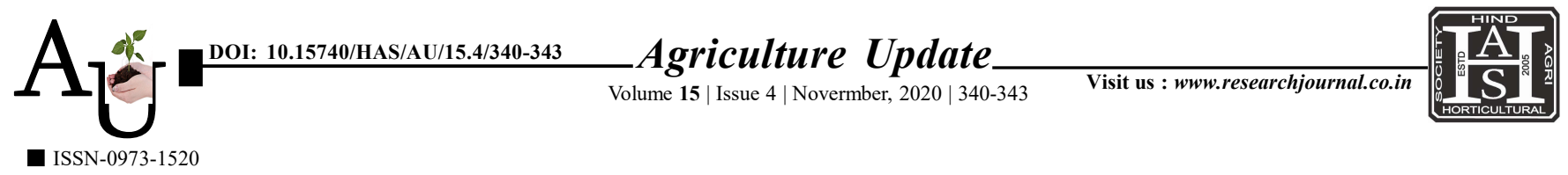

\title{
Research ARticle: Constraints faced by beneficiary and non-beneficiary red gram farmers
}

S. Prashanth, S.G. Aski and S.H. Gotyal

Article Chronicle:

Received :

23.04.2020;

Revised:

30.09.2020;

Accepted :

19.10.2020

KeY WoRds:

Constraints faced,

Beneficiary, Non-

beneficiary, Red gram

farmers

Author for correspondence :

S.G. Aski

Department of

Agricultural Extension

Education, College of

Agriculture (UAS),

Vijayapur (Karnataka)

India

Email: askisubhash@

gmail.com

See end of the article for authors' affiliations
SUMMARY : The research was conducted in Vijayapura district of Karnataka during the year 2019-20 with the sample size of 120 respondents. The findings revealed that, in case of beneficiary farmers were majority $(73.33 \%)$ of the farmers expressed non-availability of labour, followed by lower price of produce at the time of harvesting $(68.33 \%)$, storage pest problem $(63.33 \%)$ and lack of storage facilities and non-availability of credit in time $(61.67 \%)$ as problems faced by them. It was also found that, 58.33 per cent of the farmers expressed non-availability of fertilizers at the peak time as the constraint, followed by lack of transportation facilities ( $48.33 \%$ ), high cost of fertilizers ( $43.33 \%$ ), lack of marketing facilities (41.67\%) and knowledge about use of weedicides (28.33\%). In order of priority in case of nonbeneficiary farmers were majority $(71.67 \%)$ of the farmers expressed lack of storage facilities, followed by lower price of produce at the time of harvesting (66.67\%), non-availability of labour and nonavailability of credit in time (61.67\%) and storage pest problem $(60.00 \%)$ as problems faced by them. It was also found that, 56.67 per cent of the farmers expressed high cost of fertilizers and lack of transportation facilities, followed by lack of marketing facilities (51.67\%) and knowledge about use of weedicides $(40.00 \%)$.

How to cite this article : Prashanth, S., Aski, S.G. and Gotyal, S.H. (2020). Constraints faced by beneficiary and non-beneficiary red gram farmers. Agric. Update, 15(4): 340-343; DOI : 10.15740/HAS/AU/15.4/340-343. Copyright@2020: Hind Agri-Horticultural Society. 